\title{
Ethical Values of Daily Living Space Perspective-Based on the Vision of a Better Life
}

\author{
Chen Cong-lan \\ Institute of Ethics and Contemporary Moral Education, Xi'an Technological University, Xi'an, China
}

\section{Email address:}

Chencconglan@163.com

\section{To cite this article:}

Chen Cong-lan. Ethical Values of Daily Living Space Perspective-Based on the Vision of a Better Life. International Journal of Philosophy. Vol. 6, No. 3, 2018, pp. 61-67. doi: 10.11648/j.ijp.20180603.11

Received: August 12, 2018; Accepted: August 28, 2018; Published: September 28, 2018

\begin{abstract}
The object of life is the person with realistic needs and transcendence, which means the good life essentially begins and connotes the beauty of living space. This paper analyzes the value of living space from the perspective of better life, by means of modern theory of space, and reveals that the beauty of living space does not only lie on its material basis for human existence, but also constitute the origin and origin of life. At the same time, it shapes the sense of identity and belonging of human beings to home, homeland and to the country in a unique way. Moreover, on the level of transcendence, human beings permeate their own understanding of the world, hopes and beliefs, the relationship between man and the world, and the pursuit of lofty and eternal in the construction activities, and getting the most amazing presentation and expression through the form of architecture. Therefore, the good life is based on the satisfaction of the living space, the attribution of the living space is the value appeal, and the transcendental connotation of the living space is the ultimate goal, all of which constitute the three value dimensions of the living space.
\end{abstract}

Keywords: Good Life, Living Space, Residential Building, Sense of Belonging

\section{Introduction}

As the ideal condition of human life, a good life essentially begins and connotes a nice living space. People live in the earth, through their own practices of production and life, constantly transforming the natural space into "social space", a living world, and forming a specific spatial form of residential, public buildings and settlement areas. At one time, because of the "forgetting" of space, these forms of space were regarded as the machines of residence, and only containers that had nothing to do with the human mental system. However, space research initiated by Lukács, Lefebvre, Foucault, etc. in the last century pointed out that these spaces are "live: it can say something. It has an emotional core or center: ego, bed, bedroom, apartment, and house; or a square, a church, a cemetery. It surrounds the heart of passion, action, and living situations, and directly implying time", [1] they participate in the process of shaping human nature. By introducing the concept of "dark matter" in cosmology, the modern technical philosopher Latour also revealed that artifacts are active "dark matter". He believes that any artifact, no matter how unobtrusive, "affects the decisions we make, the outcome of our actions, and the way we exist in the world".[2]Residential buildings, cities, street and squares are important artifacts in the world of life, playing a vital role in shaping people's ethical consciousness. So today a correct understanding of good life must go beyond the ontological presupposition of the dichotomy between the traditional subject and the object, to pay attention to the space in which the subject of life is placed, and explore its material, emotional and transcendent implications in the pursuit of a good life, which is also the fundamental meaning of human life ethic.

\section{Living Space Is the Material Basis for Existence and Life of Human}

A good life must be based on the fundamental needs of people for food, clothing, housing, etc. Basically speaking for level of human existence, "the original instinct of all living beings is to find a place to live", [3] the living space should be the first object that must and should be satisfied, especially since human beings entered the era of settled civilization. Established by the living space and life world, Husserl pointed 
out that it is an area of "intuitively given", "pre-scientific, intuitive" and "experimental" field, it has a difference of "the world of daily life" in contrast to the "non-daily world", accordingly, of living space can also be divided into "everyday living space" and "everyday living space", the latter being based on its basic and authenticity for human survival and ethical shaping, it becomes the core of the study of residential ethics. According to the scope of daily activities, the everyday spaces of living are mainly divided into three levels: microscopic and pure private life field, such as family residence; Middle view of many areas of public life, such as community, square, and the transitional space like streets; And macro rural or urban settlement areas. The three types of living spaces together constitute the world of daily life, intertwined into a multi-dimensional and indispensable picture of human life.

Among these living spaces, the residence undoubtedly occupy the most basic, fundamental and core position, and are the necessities and fundamental interests of human existence. As Marx pointed out, human beings can only survive by relying on products that are manifested in housing, food, fuel, clothing, and so on. [4] As a basic human's right, "a man who wants to live owns a house" plays a vital role in shaping human nature and forming moral consciousness. Because the residential place is a shelter shielding against natural threats and ones from others. Historically, human beings have learned to building, constructing, and planning for the sake of shelter and protection. From the simplest cave dwellings, nesting, ground-structured houses to modern reinforced concrete buildings, no matter which form, it serves as a life and property for the shelter. For thousands of years, people have gained security in their houses, preserving and relaxing their bodies, and providing material convenience and guarantee of humanistic and ethical significance for reproduction and breeding of life, for the basic content of survival. As is known to all, the reproduction process of human life is carried out by means of labor and reproduction. The former is the reproduction of individual life, which meets the life process or survival needs of human. Only with the aid of labor, can human beings can guarantee their survival, and "the residence constitutes the condition of labor". The possession is the extension of our body. But the body as a naked one is not the original possession. It is still out of possessions and non-owners. Under the residing, can we dominate ourselves, "for those without a residence, labor will be impossible".[5]This is especially important in traditional societies, in the house, family members cooperated closely and work together to obtain the necessities of life for themselves and the family through family handicraft and commercial activities, so as to ensure the reproduction of individual life. The typical house in the medieval countryside of Western Europe - the long house, of which courtyard contains pig houses, threshing ground, sheep pens, barns, and an oven for drying grains. [6] "Procreation" is another production of life, which relates to the continuation of individual life and family clan. In the traditional society with underdeveloped public facilities, procreation is almost done in the residence, and from birth to death, the individual is nearly connected with the residence, moreover, due to the social and political ethical significances of the residence, it has become the material premise for people to stand on the society and obtain social qualifications. In a larger part of the period of history, the premise that people were recognized and accepted by society was the residences they owned, which closely connected the individual with the society, and became the material symbol of the individual's social qualification. "If a person happened to lose his house, it meant that he had automatically given up own citizenship and protection from law". [7] This kind of person was regarded as a humble person by Aristotle. Tearing down or depriving the house, which was to say depriving him of his identity as a member of the group, meant a death in the social sense. In modern society, the function of the residence to protect the body and provide basic material conditions for survival has not changed, it is still the center of life, and people are relaxing from the tension, anxiety and tiredness of "non-daily space", to get necessary rest, recuperation and to store forward energy.

Secondly, many public life fields with their functions are the products of human social attributes, which constitute an important place for people to communicate and express themselves. Among them, the most closely one related to daily life is Li Fang or community. Because of human's community instinct, they have been an important life community of people since ancient times. The community is different from the family residence, which belongs to the pure private field, and aiming at protecting the personal, property and moral exclusivity of family members, while the community is a public space opening to all residents. But compared with "society", the community is a social entity that lasts and has a truly common life, of which core lies in the closed space of the home. [8] Therefore, the community has a quasi-private feature, especially in the community wall culture of China since ancient times. Individuals and families realize their social instinct in the community life, and satisfy the need to communicate with others. For individuals, the community becomes a starting point towards a broader worlds, the state uses the community to bring the daily life of the residents into the orbit of the political order. In addition, there are lane, street, square and other public spaces. As important elements of a city, as Jacobs pointed out, while ensuring people's daily passage and rest, it is more important to "promote people's friendship and interaction, and jointly achieve goals that they cannot achieve alone", [9] during the satisfaction of this social interaction needs, to cultivate their sense of public, responsibility, etc, thus the public spaces are often hailed as the lounge of the city.

Finally, it is the whole living environment of settlement space, including natural material environment such as productions and climate, mountains, rivers, and artificial systems shaped and constructed by human culture, both of which will fundamentally determine the health of people and the development of daily life, as the basic material element of human existence. The ability to group makes people gather together in some way, forming the main settlement space, until 
now, rural and urban, which become the "point of arrival" of existence, "like a magnet to attract people, arouse people's expectations", giving residents a common trait and temperament that allow them to interact, exchange goods, and communicate ideas and emotions. [10] Among them, urban space always has been the main stage for people to gather since down the ages, it contains a complex, integrated daily life, where although people are increasingly losing the good natural environment and health, they can perceive and experience the vastness and richness of the world of life, creating more possibilities for existence. It is based on this premise that Aristotle saw the city-states as self-sufficient, thinking that people lived there for a better life. Today, the cities are more important living space than before, the cities or show a fear to "others" and violence, or emerge the city as a free land, a utopia where everyone can get a free development and self-realization, perhaps be recognized as a familiar, ethical, and protected real-life environment. Regardless of the form, it is opposed to an imaginary or empirical rural settlement, the nature of which is fundamentally defined by architectural form such as homes, government buildings, commercial buildings, temples and museums. While meeting the basic living needs of people, what's more, the buildings in the settlement space are shaping the corresponding temperaments and ethical spirits of the residents through their own sacred or secular, desire-driven or rational and dignified, open or closed features.

Straightforwardly, the good life must be built on the satisfaction of living space centered on the residence. As a necessity for human survival, these living spaces accommodate and expand the daily life of human beings, such as nature, gathering, public and private, so that people living in them form their own unique lifestyle and spiritual temperaments, and passing them down from generation to generation in these spaces. Therefore, any country that strives for a better life must looks upon people the satisfaction of needs to "everyone should owns house" and other living spaces as the starting point, maximizing the production and just distribution of these spatial resources.

\section{The Living Space Shapes and Generates People's Belonging Feeling}

In addition to the material satisfaction from living space, the good life should also be attributed to the soul, that is, persons feel in their hearts that they belong to a certain space and the valuable psychology of the life style specified by this space. From inward, a man never wants to wander at will, so he will tie his body and mind to a particular region, and thereby settle down, so that the soul sojourned in the body will be settled and at peace, and when they wander outside, there is an original place to return and dream. As Mr. Latour points out: "behavior isn't only the result of the individual's will and the social structure in which a man lives, but also of the physical environment." [11] when people divide the natural space into various forms of living space, such as internal and external, far and near, high and low, human natural social psychology and emotions are also constructed at the same time. For the living space, "identifying and locating form the overall structure of residence" which are common feature of living space. [12] Therefore, "sense of orientation" and "sense of identity" constitute the two main contents of the sense of belonging in living space.

Among them, "sense of orientation" is the psychological foundation of belonging. The so-called "oriental sense", refers to the sense that people determine their own existence in a certain place and time. It mainly comes from the relationship of space controlled or dominated by people. The basic image of living environment constituted by architectures can then be carried out all the daily practices. It reflects a person's ability to discern direction and "orientation", which needs these living spaces to have their regularity and peculiarity. From the perspective of the value of human existence, the goal or center is the most important for the positioning of human existence. Bollnow believed: "the center is the spatial location of people's mental existence, where people are wandering around and living in space." [13] Residence is the center of daily life, and the starting point that we approach to the world. "The proximity to the world is produced in such a movement: this movement starts from the utopia of the residence, passing through the space to carry out the original pries, and to grasp and take away". [14] The community is the center where we move from urban space to daily life, public buildings are the center of existence which needs us to express while locating in the forest of the city, the settlement space is the center of life that is different from "the other world". Shortly, the center is the basis for behavior to reach and leave. Because of the center, the individual knows where he is from, where goes, and never be lost. The center means a familiar space opposite to the unknown and frightening outer space around it, and therefore contains the relationship between the outer and the inner. According to the center, we can divide people into relatives at home, acquaintances in the community, and passers-by who live outside the community. Meanwhile, it constructs a structure diagram of space value, in which emotions changes from thick to thin with space varying from home to neighborhood, hometown and even country, that is to say from near to far. So building of a good life today requires thinking about the issue how to shape "the sixth ethic", named how to treat friendly passers-by. And directions, the four orientations like east, west, north and south supply the main reference systems for people to locate. The ten directions of up and down, left and right, etc., make the human being much precisely embody in a three-dimensional earth, "In some cases, direction has become the main symbol of people's existence in the world". [14] In urban space, the location of the street is the most important, and those clear roads of city can lead daily actions to an accurate target. The central axis of ancient Chinese cities, the streets that ran from east to west and north to south, the lanes and Hutongs split the city at all into orderly spaces, organized and planned social life, as a result constructed the spiritual space of Chinese people. [15] Whereas as Benjamin describes Paris: a maze organized by 
roads and tunnels, so getting lost is his basic understanding of Paris. Today, when we are locating ourselves most of cities in China: standard large-scale streets, intricate transportation networks, lack of humanity and dazzling signs, similar buildings and facilities, etc., which lead people to lose their sense of direction and being, and thus their senses of belonging to urban living space.

"Identity" is the essence of belonging, which means that we understand and own the world of life, and are possessed by them. Identity involves self-construction, which is the source of meaning and experience in life. There are three forms and sources to construct identity: Legitimizing identity, Resistance identity, and Project identity. Whatever any identity, can it be expressed and presented in space, [16] as an important public building, the traditional theater is generally the most important public space for the generals to enjoy culture, socializing, accepting education and even participation in political activities. Watching drama itself is of great significance, to improve people's political, cultural and artistic accomplishment, and enhance their senses of collective identity and belonging. [17] The Parthenon, built between 447 $\mathrm{BC}$ and $431 \mathrm{BC}$, represents the identity of the Athenian citizens for the great Athens and the public interest. It is the result of the efforts of all citizens. The significance of the temple is to declare the greatness of the state Athens, and its greatness focuses on that citizens attached to all interests. "In Greek Polis, for an Athenians like Pericles, means much more than a place name on a map: it mirrors a place where people can live together. The appearance of the Parthenon temple raised the collective civic values of Athens. It stands at a location that can be seen throughout the city, whether a newly expanded urban area or an old one, you can see this united symbol shinning in the sun". [18] For human beings, the sense of identity attached to these architectural spaces is based on orientation, and expressed by the subject's memory of life environment which is built by those familiar buildings and spaces. Human's "need for memory is one for history", [19]Memory connects the past of human life with the present, each memory always belongs to the past contents of a certain space, a person in a certain space and a story in a certain space. We will "fall in love with a city because of a love, on account of a street, we fall in love with a city. To love a city, firstly you must favor a certain street of the city, for there is your favorite bar, bookstore, lover, sunshine or a cup of coffee" [20]. Through those memories of space, people have a deep identification with the world of life, and this kind of feeling turns existence into meaningful one with root as well story. That is so, according to the needs of this kind of identity, people put the physical house into a warm, feeling "home", become the space in which people can be affected by the meanings of life, and extend to other spaces according to their senses of identity with their homes. Out of the house, human will turn "the outside of home" into "homeland" and "hometown", and to learn love and respect in the interpersonal relationships produced by these spaces, accepting love and being respected, feeling joy of success and the sorrow of frustration, and then to die peacefully in the same spaces, which have perfectly interpreted the beauty of life.

A good life looks on as the sense of belonging, that is, the meaningful connection between man and the world of life, which is directly stipulated by the space and quality of life. It is through this sense of belonging that individual "stands on the ground", enriching their emotional needs, and to gain the meaning of existence and life. Appropriate spatial scale, good environment and harmonious interpersonal relations always provide people with more sense of belonging, and an ethical matrix will be established that presents an orderly and valuable life state between people and their environments, on the contrary the space too broad or forced will mislead people to chaos themselves, "the space determined by the coordinates inside is often mixed with the 'represented space', people often cannot distinguish themselves from the outside world, and completely lose in the infinite fields around themselves", [21] as a result, which will breed many negative feelings like unconquerable strangeness and fear. In a word, the good life must starts from the reflection and construction of the attribute of living space.

\section{Living Space Arches and Highlights the Pursuit of Human Value}

A good life begins with the beauty of living space, which is more than the satisfaction of material and ethical psychology, but has the dimension of transcendence. The ancient Greeks believed that the human nature contained the divinity, the presence of man and god, the preservation of man's divinity is "ethos", and "ethos is the patron saint" (Heraclitus). The Confucianist, on the other hand, is dedicated to the distinction between human and beasts, they endowed human dignity with benevolence, righteousness, propriety and wisdom, and would become sanctified through "living in benevolence". Therefore, human beings with transcendent nature always infiltrate their pursuits of immortality into their own constructing activities, and during the construction of living space, express and present their own understanding, hope and fear of the world, relationships with the world, and pursuits of nobility and eternity.

On the one hand, living space essentially expresses the ultimate meaning of existence, namely the unity of heaven, earth, human and god. For Heidegger, since human nature contains god, their residences between heaven and earth can be limited to ones, and the place where they are staying, knowing, loving and habiting must be open up to god's presence [22]. Furthermore, the residence mainly means that people have a world made up of various things, and consciously express the world through works designed by themselves, building is one of the most important things or works, while it has provided people with a world or the foundation of existence, also showing the world structure understood by human, which makes "all the buildings are regarded as solemn and sacred ones, in other words, the way that you build houses and dwell in them faithfully reflects your belief concerning with world where you live in, and the 
relations between you and the creator of the world" [23]. Throughout most of human history, settlement spaces have always revealed the internal universal order of the world in a particular way. People in the Shang and Zhou Dynasties believed that "the sky is opposite to the earth, and the heaven and the earth are composed of a symmetrical and harmonious center and four sides. The important position is higher than the four sides, and the four sides must surround the center. Each of them has a star, and is connected with the four seasons." [24] The so-called "imaging in the sky, forming in the ground" (Zhou Yi), according to the plan of this religious cosmology, the ancient Chinese cities as a whole formed a kind of "metropolis" order that organically combines time with space: the wide imperial avenue connecting the earth with the sky, and together with the east-west parallel streets, divides the urban space into an abstract model (The Magic Square), which symbolizes the earth nourishing life and on which humans depend, among which all the architectural elements such as streets, temples, gates, and Lifang are based on the laws of universal space, declaring publicly the eternal spirit of the universal order and the transcendence of harmony between man and nature. The Roman Empire's Pantheon symbolizes these Gods support for Rome's domination of the world in a harmonious way. [25] Today, those Nordic towers and domes, which combine local, cultural and historical meanings, whether they are churches, town halls, or houses, at all "show the relationship between heaven and earth, and the existence of people between heaven and earth", [26] so human beings like swallows build the world by instinct---- a huge nest that combines the earth and the sky, death and life, and two kinds of time, one is available at this moment, the other untenable." [27] In this way, the whole world are constructed into an ever-expanding geometrical order. Each link of life carried out around a "meaning center", which leads human existence to meaningful one. Thus, to some extent, it can be said that the history which human seek for a better life is one making the spaces constructed and living world meaningful. These spaces do not only bear our physical body, but also link the heaven and earth, human and gods, the unity of heaven, earth, human and gods is the true nature of human beings and their residences.

On the other hand, living space also expresses human's pursuit of immortality, no matter a church, a residence, a tower, or a museum, etc. no one doesn't reflect human's fear of time and love for space. Therefore, there is a saying that "all buildings have religious significance". [28] Human beings are mortal, which isn't reflected only in the unidirectional time of life, but also in the finiteness of living space, while restricting the survival and development of human beings, they have also become the original cause why human beings have insisted in exploring the road to rescue and liberate themselves for thousands of years. So we always strive to pursue a human's life beyond the limits of nature, and obtain the power to transcend time and space, from infinite to unlimited, that is "immortality." In different value systems, the mechanisms for achieving immortality are incoherent. The westerner is realized by the aid of the faith for Being and the kingdom of heaven, of which nature is another space eliminated features of space and time, the "immortality" of life means that the flesh remains in this world, while the spirit exists in the kingdom of heaven forever. In the Confucianism-based cultural system, the transcendence of life is completed by means of two parts, one is the immortality of the flesh, which is mainly accomplished by the reproduction of life itself, another is of the spirit, which mostly depends on the virtue and spiritual realm to achieve. In the Master Zuo's Spring and Autumn Annals, the Shu Sun-bao called "to build virtues, words and achievements", named "three immortality" which are the spirituous immortality. The Confucian freezes the pursuit of immortality in the daily activities how to respond. Although there is different between the cultural mechanism of the pursuit of immortality in China and one in the West, consistent in phenomenology, that is, through the objectified architectural space as a symbol, the hope and pursuit of mankind are spoken out, presented and inherited. In the West, the sacred place that connects the earth with the kingdom of heaven -- the churches are valued, people there have built countless magnificent, soaring churches, which are "the heaven on this world" for believers, into which people have poured most of their lives and aspirations. In the humanistic cultural system of China, immortality justly is in daily life, therefore almost all buildings, whether imperial palaces or simple houses of ordinary people, are constructed in the dwelling form, and then become "churches" of Chinese people. Until now, no other nation can be so enthusiastic for housing as Chinese. These spaces carry the consistent pursuit of eternal life and the immortal spirit of the Chinese people, and enable people in them to feel the sense of existence from which life comes from, the sense of mission as an important part of the flow of life, and the sense of the holy of life from the finite to the infinite.

Not only people express their desires for immortality through the Yang Houses, but also the eternal order and existence in the symbolic form of the Ying Houses (mausoleums). In ancient Egypt, "the residence of the afterlife" is the basic architectural task, "it (mausoleum) shows a dynamical order that is closely linked to the structure of Egypt's nature and the landscape of the earth". [29] In China, "if the pyramidal tomb in the Li Mountain is a symbol of Qin Empire's absolute power, then the coffin chamber under ground is consciously built into a cosmic model". [30] Human beings who believed in the immortality of soul thought that the tomb was the homes and life worlds of the dead persons, and through the vital belief of ancestor- worship, the spirit of "to serve death as a matter of life" was deeply permeated into the ethical idea of generations. Therefore, the cemeteries are not the lonely world of the dead, but the center of social activities, a public living space to unite ethnic groups and families together. For those that are alive, these deceased peoples never leave them, but live among them, and sharing the honor and disgrace with their families and clans.

Additionally there are other forms of residential architecture expressing this transcendental pursuit. For 
example, the museum is known as the "church of art", which contains all human works and endows human civilization with immortality. Since modern times, monumentality buildings are the spaces which bear the weight of national immortal souls, symbolizing that people have obtained the ethical significance of existence beyond their own mortality. Today, they are spread all over the settlement space, and while turning history into a part of everyday life, to tell people that "only what is worth dying for has the power to make life worth living" and "only a man who oversteps individual and limited by death life can render it (life) magnificent." [31]

In short, for thousands of years, it is through their own architectural activities and the numerous great buildings created in the grand mass, transcendence and shocking ways, that human beings have expressed their weaknesses and hopes, while bearing their own meanings of existence to satisfy their own transcendences, and elevated people's survival activities into a kind of essence and great practice closely connected with the heavens and the earth, finally enabled people to be "full of achievements, but poetically settle on this land" (Holderlin). Besides physical spaces with scale and shape, for people these buildings are "the ruler to measure their residence and sojourn under the sky and above the earth".[32]Here is always echoing the grand rhythm of universe concerning with human past, present and future, life and death. In this sense, only the contents that implicate transcendence can finally achieve the beauty of human space, forwardly, the beauty of space can complete the beauty of human life.

\section{Epilogue}

As Foucault asserted that the anxieties in our times couldn't clear fundamental relationships with spaces. The space of human life is an indispensable important dimension to consider human life, and a dead method to examine the meaning of human existence. The living space is closely related to the essential needs of human beings and the most basic content of daily life. It embodies the imagination of human beings, contains human emotions and meanings, and holds on to the pursuit of human values, a real and imaginary, concrete and abstract, actual and metaphorical, open and constantly generating space, a rich and extensive space. The contemporary era, to meet the demand that the people long for better life has become the vital goal to realize the dream of China, and the good life is defined and expressed by the nice living space. It should not be overlooked that our daily lives and daily spaces are facing with the squeezing and controlling of multiple ethical contradictions, as a result the strangeness, anxiety and meaninglessness generated are dispelling the value of life and meaning of life that we definitely confirmed, however which is also a hopeful space filled with various possibilities, because it will inevitably challenge the ethical awareness such as empiricism, volatility and exclusivity of daily life, thus the challenge means transformation and reconstruction!

\section{Acknowledgements}

This paper is supported by the National Social Science Fund Project of China "16BZX084".

\section{References}

[1] Henri Lefebvre. The Production of Space. trans by Donald Nicholson-Smith, Blackwell Publishing, 1991. p. 42.

[2] B, Latour. Where Are the Missing Masses? The Sociology of a Few Mundane Artifacts. In: Bijker, W. E. and Law, J. eds. Shaping Technology/Building Society: Studies in Sociotechnical Change, MA: MIT Press, 1992, p. 225-258

[3] Le Corbusier, Towards New Architecture, translated by Chen Zhihua, Beijing: The Commercial Press, 2016, p. 7.

[4] The Economic and Philosophical Manuscripts in 1844, The Anthology of Marx and Engels (Volume I), Beijing: The People's Publishing Press, 2009, p. 161.

[5] Emmanuel Levinas, Overall and Unlimited----On Externality, translated by Zhu Gang, Beijing: Peking University Press, 2016 , p. 145.

[6] Philippe Ariès: The History of Private Life, Volume 2, translated by Hong Qingming, Harbin: Northern Literature and Art Publishing Press, 2007, pp. 396-397.

[7] Hannah Arendt, The Man's Situation, translated by Wang Yuli, Shanghai: Shanghai People's Publishing House, 2012, p. 41.

[8] Philippe Ariès: The History of Private Life, Volume V, translated by $\mathrm{Li}$ Qun, The Northern Literature and Art Publishing Press, 2007, p. 95.

[9] A. B. Jacobs, The Great Streets (Introduction), translated by Wang Youjia, Beijing: China Architecture \& Building Press, 2009 , p. 7.

[10] K. Norbert Schultz: The Dwelling Conception, translated by Huang Shijun, Beijing: China Architecture \& Building Press,, 2012, p. 29.

[11] P. P, Verbeek. Acting Artifacts: the Technological Mediation of Action. In: Verbeek, P. P. and Slob, A. eds. User Behavior and Technology Development: Shaping Sustainable Relations between Consumers and Technologies. Dordrecht, Netherlands: Springer, 2006.

[12] The Dwelling Conception, p. 13.

[13] O. F. Bollnow, Mensch und Raum, Stuttgart 1963, p. 58. Referred to The Residential Conception, p. 20.

[14] The Dwelling Conception, p. 22.

[15] See Chen Conglan, On Chinese Urban Ethical Spirit and Its Construction, Research of Ethics(2017) 3,

[16] Manuel Custer: The Power of Identity, translated by Cao Rongxiang, Beijing: Social Sciences Academic Press, 2006, pp. 6-7.

[17] See Yuan liangzhong, The Public Space Attributes of Returning to Theater, Zhejiang Journal (2015) 1.

[18] Richard Sandett, Flesh and Stone, Body and City in Western Civilizations, translated by Huang Yuwen, Shanghai: Shanghai Translation Publishing House, 2006, pp. 11-12. 
[19] Astrid El, Theory Reader of Cultural Memory edited by Feng Yalin, Beijing: Peking University Press, 2012, p. 100.

[20] Li Guoqing, New Streetism, New Weekly (2002) 1

[21] Celeste Oraquiaga, The Big City: Contemporary Cultural Awareness, Minnesota University Press, 1992, pp. 1-2. Quoted from Edward Sawyer, The Third Space, translated by Lu Yang, Shanghai: Shanghai Education Press, 2005, pp. 251-252.

[22] Heidegger, Wegmarken, Vittorio Klostermann, Frankfurt am Main 1978, S. 353. Cited from Han Chao: Heidegger and Issues of Ethics, Shanghai: Tongji University Press, 2007, p. 9.

[23] David stancliffe. The Architecture of churches, translated by Wu danqing, Zhengzhou: Great Elephant Press, 2013, p. 7.

[24] Ge Zhaoguang. The history of Chinese thoughts. Shanghai: FudanUniversity Press, 2001, p. 51.

[25] Flesh and Stone, the Bodies and Cities of Western Civilization, p. 67.

[26] The Dwelling Conception, p. 39.
[27] Notes of G. L. M, 1954, The Volume of Autumn, translated by Andre du Bouchet, p. 7, cited from Gaston bascher, Space Poetics, translated by Zhang Yijing, Shanghai: Shanghai Translation Publishing House, 2016, p. 133.

[28] Walter Pichler and Hans Hollein, Absolute Architecture, in Programs and Manifestoes on $20^{\text {th }}$-Century Architecture, ed Ulrich Conrads, trans. Michael Bullock (Cambridge: MIT Press, 1975), p. 181.

[29] Christian Noberg-Schultz, The Significance of Western Architecture, translated by Li Wei, Beijing: China Architecture \& Building Press, 2005, p. 11.

[30] Wu Hung, The Monumentality in Ancient Chinese Art and Architecture, translated by Li Qingquan, Shanghai, Shanghai People's Publishing Press, 2017, p. 199.

[31] Carsten. Harris, Ethical Functions of Architecture, translated by Shen Jia, Beijing, Huaxia Press, 2002, p. 294.

[32] Heidegger, Man, Poetically Dwelling, translated by Yu Yuanbao, Shanghai: Shanghai Far-east Publishing House, 1995, p. 94. 